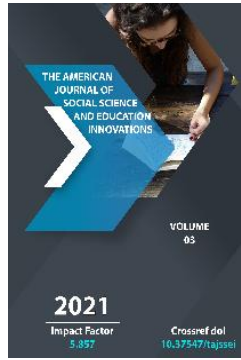

\title{
Education Of Spiritual And Moral Virtues In Students In English Language Classes In Higher Education Institutions
}

\author{
Nigora Abdullaeva \\ Fergana State University, Fergana, Uzbekistan
}

Journal Website:

http://usajournalshub.c

om/index,php/tajssei

Copyright: Original content from this work may be used under the terms of the creative commons attributes 4.0 licence.

\section{ABSTRACT}

This article provides information on the role of English language teachers in the education of active, creative and spiritual youth, citizens of our country, the relevance of spiritual and moral education in youth and methods of spiritual and moral education.

\section{KEYWORDS}

Moral education, spiritual and aesthetic feelings, intellectuality, attributes of Western culture, disputes.

\section{INTRODUCTION}

Currently, much attention is paid to preparing the young generation for creative activity in all spheres of society. In this regard, the role of the university in the upbringing of active, proactive, creatively thinking and spiritually and morally rich citizens of the country is increasing.

To be spiritually and morally richer means to constantly and tirelessly enrich oneself, to 
grow oneself internally, to improve spiritually. Constantly expand your horizons, improve the general and political culture, satisfy intellectual needs, maintain mental performance, join the treasures of literature, art, form high spiritual and aesthetic feelings and qualities. It is the intellectual and spiritual needs that are boundless, and especially their satisfaction brings a person true happiness. The true wealth of the individual must be sought in that which serves to satisfy precisely these needs.

The radical transformations in the country have once again confirmed the need for the formation of the language culture of young people in foreign languages, including English. As you know, English continues to be the language of communication, both in the republic and abroad. Proficiency in English is one of the conditions for improving the quality of training of highly qualified specialists.

Today, educational projects for teaching the English language make it possible to provide moral education and high-quality teaching, where the development of the individual abilities of young people, aimed at revealing the natural potential of the individual, is in the first place.

\section{MATERIALS AND METHODS}

The opposition of such universal human moral qualities as good and evil, benevolence and meanness, sincerity and envy, conscience and fraud, industriousness and parasitism, mercy and cruelty, humanism and heartlessness, patriotism and betrayal in folklore help to distinguish between "grains" to develop a positive attitude to morality, moral values and norms developed by the masses in the process of centuries of struggle for freedom and social equality, for a peaceful and happy life.

Based on the historical experience of civilizations, moral criteria that have become universal, university teachers are called upon to form students' specific spiritual and moral qualities - hard work, respect for elders, humanism, a sense of collectivism, honesty, devotion, duty, conscience, truthfulness, tolerance towards people deeply rooted in the life of the common people, in national traditions, history and culture.

The key problem in the process of comprehensive and harmonious development of the individual is moral education. Only thanks to him man stood out from the animal world as a social being. The development of inquisitiveness, the mastery of knowledge, the improvement of thinking, memory and ingenuity are the core of the all-round development of the individual. It should be borne in mind that without deep knowledge and education it is impossible to transform life, be at the level of modern civilization and successfully advance along the path of socioeconomic and political progress.

In the conditions of democratization of society, freedom of opinion and belief, young people did not acquire knowledge mechanically, but deeply processed it in their minds and themselves drew the conclusions necessary for modern life and education. Only such an approach to training and education allows us to educate conscientious members of society, find ways to everything new, advanced, use the achievements of modern civilization, not succumb to the influence of erroneous and harmful political movements, and develop 
correct moral, moral and ideological-political convictions ourselves.

Parenting means introducing young people to the best of human heritage. But since most of this heritage is expressed in words, education is effective only if these words have found reality in the person of the teacher, in practice and in the structure of society. The relationship of a person to the world is possible only in practical, creative and transformative activity. Therefore, the mechanisms of the subject's internal activity, aimed at his own cognition and change, can function normatively only if he himself actively acts in the external social world, realizing himself as a morally rich person.

Moral education is a purposeful two-way process of forming moral consciousness, developing moral feelings and developing skills and habits of moral behavior. It includes the formation of moral consciousness, education and development of moral feelings, the development of skills and habits of moral behavior. Behavior is moral if a person weighs, thinks over his actions, acts competently, choosing the right way to solve the problem facing him. The moral behavior of a person has the following sequence: a life situation - a moral - sensory experience generated by it - a moral understanding of the situation and motives of behavior, choice and decisionmaking - a volitional stimulus - an act.

The most important means of moral education is the use of moral ideals created in culture at different stages of historical development, i.e. patterns of moral behavior to which a person seeks. A specific feature of the process of moral education should be considered that it is long-lasting and continuous, and its results are delayed in time. The process of moral education is dynamic and creative. The main criteria of a person's morality can be his beliefs, moral principles, value orientations, as well as actions in relation to relatives and strangers. We believe that a person should be considered moral for whom the norms, rules and requirements of morality act as his own views and beliefs, as habitual forms of behavior.

The relevance of the problem of moral education is also associated with the fact that in the modern world a person lives and develops among many diverse sources of strong impact on him, both negative and positive (mass media, communications, extraordinary events in different parts of the world, natural disasters, etc.), which constantly fall on the young individual's immature intellect and feelings, on his emerging sphere of morality. It is becoming more and more difficult for the younger generation to figure out what is true for them and what is false. Morality, as you know, is nothing more than the basis of personality characteristics, which runs like a red thread through all his activities and behavior.

Moral education should be based on the study of the socio-cultural experience of previous generations, presented in the cultural and historical tradition. After all, the value system of tradition has evolved over the centuries. It absorbed the experience of generations, influenced by history, nature, and the characteristics of the region where our ancestors lived. (In this regard, it is enough, in our opinion, to refer to such concepts as "mahalla", "hashar", etc.). That is why the upbringing of a citizen and a patriot who knows and loves his native Uzbekistan is impracticable without deep knowledge of the 
spiritual and moral wealth of his people and familiarization with its ethnoculture, as well as the great heritage of our great ancestors.

In the practice of teaching the Russian language, educational material serves the purposes of moral development and upbringing, which creates conditions for stimulating the interest of all students in the study of the foundations of morality.

Moral education is effectively carried out only as an integral process. The result of the holistic process is the formation of a morally integral personality, in the unity of its consciousness, moral feelings, conscience, moral will, skills, habits, socially valuable behavior. In his work on moral education, he uses many different methods and techniques:

- Ethical conversations (if the material allows during classes, outside the classroom);

- Ethical stories;

- Disputes (held once a month, while students choose a topic from the one suggested by the teacher);

- Written reflections on a moral theme (some of the essays are read to the group);

- Examples (heroes of fiction, heroes from real life, etc.),

- Meetings with "interesting" people (inviting representatives of law enforcement agencies, fire safety, veterans, actors, doctors, military, etc.);

- $\quad$ Trips to the drama theater, concerts.

The following methods were used:
- Clarification (mostly individual, after committing a bad deed);

- An ethical story;

- Essays on a moral theme (some are also read aloud),

- Examples of modern exploits (rescue in case of fire, drowning, natural disasters, quarantine, road accidents, etc.).

As you can see, the variety of methods for the formation of moral behavior allows you to bring up wonderful human feelings.

\section{RESULTS AND DISCUSSION}

At the same time, students are given the opportunity to comprehend and critically assess communication situations, analyze, participate in discussions, and come to certain conclusions. One of the urgent tasks of the methodology is to increase the culture of interaction between the student and the teacher. Of particular importance here is the development of conditions for successful psychological and pedagogical communication at the first stage of training, when mutual understanding is complicated by the action of a variety of barriers. To overcome them, it is necessary to build a model of flexible interaction that takes into account the characteristics of the learner and the educator.

In this regard, in practical classes in the English language, students were offered materials that, to one degree or another, would contribute to the education of both moral qualities and the intellectual development of youth. For example, the philosophical consideration of the problem of morality, morality, as shown by the English and Uzbek 
scientists - doctors, formed a person as a person, a people as a society.

Students should realize that a mistake in a person's life is a life lesson, the main thing is that a person's consciousness should understand what is the reason for his wrongness, otherwise a mistake is no longer a lesson, but a person's limitation and obsession.

So, each lesson of the English language at the university is an example of raising high moral qualities in young people, revealing moral problems that, unfortunately, exist in the modern world. A teacher in Russian studies must become and must be such - a creator who can be called a truly connoisseur of morality, who strictly adheres to his moral principles. It is clear that everyone has their own morality and the concept of "evil" is also different for everyone. There are many ways to live according to morality, and human morality is not always correct and does not carry evil in itself - this is what teachers should convey to their students.

A moral compromise is especially difficult for a person, in which an honest person receives the right to life. On such examples of their fiction, you can educate moral qualities, introduce moral values into the souls of students. In the study of the moral experience of students, a number of complementary methods were used: a conversation on life situations, a survey method, examples from life experience. In addition, the proposed system of work includes the following techniques, methods and technologies for teaching the English language on the basis of morality:

Conversation. When using the conversation, the subject was asked to listen to a story containing a moral problem. The heroes of the story found themselves in a situation of moral choice. After listening to the story, the students were asked questions, which were composed in such a way that in the answers and statements of the subjects, attitudes, knowledge about methods of behavior and about the moral standard were manifested.

Unfinished story. When using the unfinished story method, students are read a story in which the hero needed to act, either in violation of the moral norm, or in accordance with it. Each subject was asked to imagine that he himself was the protagonist. The student had to finish the story by proposing their own ways of behavior and justifying them. When determining the characteristics of the moral experience of students, the following criteria were used: the degree of compliance with the moral norm of knowledge, attitudes and ways of behavior; generalization of knowledge; their depth and breadth; degree of stability. To assess the moral knowledge of the subjects, such manifestations as their understanding of the content of moral norms, knowledge of modes of behavior, knowledge of the experiences that arise in a person in the event of compliance or non-compliance with a moral norm were singled out. They learned about the moral attitude by the value judgments of students about the actions of another person, about their actions, as well as by the characteristics of the implementation of moral activities and their motives.

Life gives not only positive, but also negative examples. It is not only desirable, but also necessary to draw students' attention to the negative in life and behavior of people, to analyze the consequences of wrong actions, to draw the right conclusions. In time to the place, 
the given negative example helps to keep the pupil from doing the wrong thing, forms the concept of immorality.

Naturally, education also depends on the teacher's personal example, his behavior, attitude towards students, worldview, business qualities, and authority. It is known that for most students the authority of the teacher is absolute, they are ready to imitate him in everything. But the strength of a positive example of a mentor increases when he, with his personality, with his authority, acts systematically and consistently, without discrepancies between word and deed, benevolently.

The dispute is a lively heated dispute on some topic that excites student youth. Disputes are valuable because beliefs, motives are developed in the collision and comparison of different points of view. This method is complex, it is used mainly in the first courses. "To rely on positive age-related needs and interests that create the effect of relevance," which ensures the emotional richness of the common activity, organizes joint collective efforts and experiences that unite its participants. Creates an atmosphere of emotional and volitional tension leading to success. It affirms a joyful, upbeat lifestyle of the student collective and each personality. It takes into account the positive impact of public opinion (interesting, important), which performs the function of emotional contamination. To take care of creating an atmosphere of benevolent mutual understanding."

Situational task. They discussed the issue of friendship with the hero of a literary work or film. - Who would you like to be friends with? -
Why? What qualities are attracted to the hero? (students want to be friends with strong personalities). - Who helps you in your life in difficult times? - How can television and literary heroes help? (it is concluded that close people help in difficult times - mom, dad, classmates, teachers, friends, relatives. Fictional heroes can help only by showing an example of strength or resourcefulness in getting out of a critical situation). Students were asked to recall situations when they learned something from a teacher, parents, watching TV or reading a book. We remembered a lot of facts confirming what we studied in the school or university curriculum. Students were offered such situations in which they had to help a classmate or friend:

"If you were walking in the yard with others and one of the guys fell down next to you and hurt your leg very badly. What would you do?

A 1st year student from a hostel fell ill, he has a high fever, severe cough, and malaise. Your actions?"

You can understand and such a topic: "Mutual respect." Purpose: to teach students mutual respect for each other, as well as for the elderly, fostering a culture of interpersonal relationships. The following situations were suggested: 1. "Show respect to the old man." The guys were divided into teams. Each team played a scene about this situation, how they felt respect for the elderly is expressed. In my opinion, the students did an excellent job with this type of work, the scenes turned out to be natural and interesting. 2. "Invite guests to the table and sit down, wish you bon appetit." The guys were also divided into teams, each team completed the task. It can be concluded that students are well aware of the rules of 
etiquette and are able to apply the knowledge gained. The teacher asked the students to draw conclusions, as well as compare the behavior of the children in everyday life. The students came to the conclusion that they are not always guided by the rules of etiquette, and they do immoral acts.

\section{CONCLUSION}

In general, I liked working with students, they willingly made contact, entered into discussions, and made their own conclusions. In addition, they turned out to be creative (artistic) personalities. It is necessary to carry out further work in the group in this direction (moral education), this will allow to unite students, develop their culture of communication and behavior. In general, the course is creative, they like to act out different scenes that they come up with themselves or on the basis of works, so further work can be directed to the development of the creative potential of young people. If in the future such work is carried out in groups with students, then they will undoubtedly be cultured, highly moral people.

Such work confirms "the regularity of moral education, which was formulated by V.A. Sukhomlinsky: "If a person is taught good - ... the result will be good." Only it is necessary to teach constantly, demandingly, persistently, in various forms, including games, taking into account the individual and age characteristics of student youth.

\section{Practical recommendations:}

1. In the learning process, it is necessary to pay attention to the following main aspects of education:
2. To ignite in their students the desire to multiply the historical experience of the struggle for a brighter future, to educate people with a strong spirit, with a developed sense of love for their state;

3. At each lesson of the English language, to form students' specific spiritual and moral qualities - hard work, respect for elders, humanism, a sense of collectivism, honesty, devotion, duty, conscience, truthfulness, tolerance towards people who have deep roots in the life of ordinary people, in national traditions, history and culture.

\section{REFERENCES}

1. Azizkhodzhaeva N.N. Pedagogical technologies and pedagogical skills Tashkent: IPT house named after Chulpan, 2005 -- $200 \mathrm{p}$.

2. Kalyuzhny A.A. The role of the teacher in the moral education of youth. - Moscow, 1998;

3. Marienko I.S. Moral formation of personality. - M., 1985.

4. Rakhimov A.Z. The role of moral education in the formation of personality. // Classroom teacher. - 2001, No. 6.

5. Rozhkov M.I., Bayborodova L.V. Organization of the educational process at the university. - $M$.: Humanit. ed. center VLADOS, 2000.

6. Kharlamov I.F. Moral education of youth. M .: Education, 1983. 
7. Shilova M.I. The problem of values and goals of education. // Classroom teacher. 2001. No. 3.

8. Muslimov N.A., Kadyrov M.M. Development of professional qualities of future teachers in the process of studying pedagogical disciplines // Young scientist. 2012. - No. 12. 